\title{
UJI EFEKTIVITAS ANTIBAKTERI SEDIAAN SABUN CAIR CUCI TANGAN DARI LENDIR LIDAH BUAYA (Aloe barbadensis Miller) TERHADAP Eschericia coli DAN Staphylococcus aureus
}

\author{
Sheila Meitania Utami, Ignesia Rara Denanti \\ Sekolah Tinggi Ilmu Kesehatan Kharisma Persada \\ Tangerang Selatan, 15417 \\ E-mail : Sheila.meitania@gmail.com
}

\begin{abstract}
ABSTRAK
Kebersihan diri merupakan suatu proses pertahanan dan pemeliharaan kebersihan serta kesehatan tubuh Langkah-langkah dalam pemeliharaan kebersihan dan kesehatan antara lain dengan mandi yang teratur, menjaga kerapihan, menggosok dan merawat gigi, berganti pakaian secara teratur dan mencuci tangan. Salah satu bahan yang dapat digunakan sebagai bahan baku alternatif untuk membunuh bakteri pada sediaan sabun cair cuci tangan adalah lidah buaya atau yang lebih sering disebut Aloe Vera (Aloe barbadensis Miller). Penelitian ini bertujuan untuk mengetahui efektivitas antibakteri dan konsentrasi paling efektif sediaan sabun cair cuci tangan dari lendir lidah buaya terhadap bakteri Eschericia coli dan Staphylococcus aureus . Formula I dengan lendir lidah buaya (3\%), Formula II (6\%), Formula III (9\%), kontrol positif dengan sabun cair cuci tangan Dettol (9\%) dan kontrol negatif tanpa lendir lidah buaya. Uji aktivitas antibakteri sediaan sabun cair menggunakan media Mueller Hinton Agar (MHA) terhadap bakteri Eschericia coli dengan metode cakram dan Staphylococcus aureus dengan metode gores setelah diinkubasi selama 24 jam. Pengujian diamati setiap 3 jam sekali selama 24 jam. Hasil menunjukkan bahwa Formula I, II dan III dapat menghambat pertumbuhan bakteri Eschericia coli dan Staphylococcus aureus yang setara dibandingkan kontrol positif Dettol 9\% dengan Formula III sebagai konsentrasi paling efektif.
\end{abstract}

Kata Kunci: Antibakteri, Lidah buaya, Sabun cair, Eschericia coli, Staphylococcus aureus .

\section{ABSTRACT}

Personal hygiene is a process of defense and maintenance of cleanliness and health of the body. Steps in maintaining hygiene and health include regular bathing, maintaining neatness, rubbing and caring for teeth, changing clothes regularly and washing hands. One of the ingredients that can be used as an alternative raw material to kill bacteria in hand washing liquid soap is Aloe Vera or Aloe Vera (Aloe barbadensis Miller). This study aimed to determine the effectiveness of antibacterial and effective concentration of liquid hand wash from Aloe vera mucus to Escherichia coli and Staphylococcus aureus bacteria. Formula I with Aloe vera mucus (3\%), Formula II (6\%), Formula III (9\%), positive control with Dettol hand wash (9\%) and negative control without aloe vera mucus. Test of antibacterial activity of liquid wash preparation using Mueller Hinton Agar (MHA) media against Escherichia coli using disc method and Staphylococcus aureus bacteria using scratch method after incubation for 24 hours. Tests were observed every 3 hours for 24 hours. The results show that Formula I, II and III can inhibit the growth of Escherichia coli and Staphylococcus aureus bacteria which are equivalent compared to Dettol 9\% as the positive control with Formula III as the most effective concentration.

Keywords: Antibacterial, Aloe vera, Liquid wash, Eschericia coli, Staphylococcus aureus . 


\section{PENDAHULUAN}

Kebersihan merupakan kunci dari kesehatan, manusia perlu menjaga kebersihan diri agar tubuh menjadi sehat, sehingga tidak menyebarkan kotoran dan tidak menularkan penyakit, baik bagi diri sendiri ataupun bagi orang lain. Kebersihan diri merupakan suatu proses pertahanan dan pemeliharaan kebersihan serta kesehatan tubuh. Langkah-langkah dalam pemeliharaan kebersihan dan kesehatan antara lain dengan mandi yang teratur, menjaga kerapihan, menggosok dan merawat gigi, berganti pakaian secara teratur dan mencuci tangan (Timmreck, 2008).

Mencuci tangan adalah salah satu tindakan dengan membersihkan tangan dan jari jemari dengan menggunakan air ataupun sabun (Siswanto, 2010). Sabun merupakan suatu kebutuhan pokok manusia yang selalu digunakan yang sehari-hari. Fungsi utamanya adalah membersihkan di lingkungan sekitar. Banyak macam wujud sabun yang banyak ditemui, baik yang dalam bentuk cair, lunak, krim maupun yang padat. Kegunaannya pun beragam, ada yang sebagai sabun mandi, sabun cuci peralatan rumah tangga, sabun cuci tangan dan lain sebagainya (Herbamart, 2011). Mencuci tangan dengan menggunakan sabun terbukti secara ilmiah efektif membunuh bakteri dan mencegah penyebaran penyakit-penyakit menular seperti diare, Infeksi Saluran Pernapasan Atas (ISPA) dan membunuh kuman Penyakit atau bakteri yang ada ditangan (Proverawati dan Rahmawati, 2012).

Salah satu bahan yang dapat digunakan sebagai bahan baku alternatif untuk membunuh bakteri pada sediaan sabun cair cuci tangan adalah lidah buaya atau yang lebih sering disebut Aloe Vera (Aloe barbadensis Miller) (Furnawanthi, 2007). Lidah buaya mengandung senyawa saponin yang mempunyai kemampuan membunuh kuman, emodien antrakuinon yang sebelumnya telah terbukti memiliki aktivitas antimikroba.

Antrakuinon bekerja dengan cara menghambat sintesis protein sehinggan bakteri tersebut tidak dapat tumbuh dalam media yang terdapat lendir lidah buaya (Teresya Puteri, 2013). Serta senyawa kuinon sebagai antibakteri dan penghilang rasa sakit. Saponin terdapat pada cairan bening seperti jeli diperoleh dengan membelah batang lidah buaya. Jeli ini mengandung zat antibakteri dan anti jamur yang dapat menstimulasi fibroblast yaitu sel-sel kulit yang berfungsi menyembuhkan luka (Sulaeman, 2008). Selain kedua zat tersebut lidah buaya juga memiliki banyak kandungan kimia dan diantaranya kandungan utama adalah air dan polisakarida (pektin, hemiselulosa, 
glukomanan, asemanan dan derivat manosa). Selain itu juga mengandung asam amino, lipida, sterol (lupeol,

\section{METODE}

\section{Alat dan Bahan}

Alat yang digunakan dalam penelitian yaitu autoklaf, laminar air flow, batang pengaduk, cawan petri, erlenmeyer, gelas ukur, penangas, lampu spiritus, paper disk, jarum ose, pinset, pipet tetes, jangka sorong, $\mathrm{pH}$ meter, oven, inkubator, gelas beker, labu takar, kaca arloji, eco pipette dan mistar berkala.

\section{Preparasi Sampel}

Sampel diambil dari Badan Pengkajian Penerapan Teknologi (BPPT) PUSPIPTEK Serpong, Tangerang Selatan. Sampel yang diperoleh segera kamposterol dan sitosterol), tanin dan enzim (BPOM, 2008).

Bahan yang digunakan dalam penelitian yaitu lendir lidah buaya, asam stearat, $\mathrm{NaCl}, \mathrm{NaOH}$, gliserin, EDTA, aquadestilata, bakteri Eschericia coli, bakteri Staphylococcus aureus, medium Nutrien Agar (NA), medium Mueller Hinton Agar (MHA) dan sabun Dettol $9 \%$.

dicuci bersih kemudian diambil daging buahnya lalu diblender sehingga diperoleh lendirnya dan disaring..

\section{Formulasi Sabun Cair Cuci Tangan Lendir Lidah Buaya Tabel 1. Komposisi Formula Sabun Cair Cuci Tangan Lendir Lidah Buaya (Aloe barbadensis Miller)}

\begin{tabular}{lccccl}
\hline \multirow{2}{*}{ Bahan } & \multicolumn{5}{c}{ Formula \% (b/v) } \\
\cline { 2 - 6 } Lendir Lidah Buaya & KN & F I & F II & F III & Keterangan \\
\hline Asam Stearat & - & $3 \%$ & $6 \%$ & $9 \%$ & Zat aktif \\
\hline $\mathrm{NaCl}$ & $3 \%$ & $3 \%$ & $3 \%$ & $3 \%$ & Pengemulsi \\
\hline $\mathrm{NaOH}$ & $1 \%$ & $1 \%$ & $1 \%$ & $1 \%$ & Pengental \\
\hline Gliserin & $1,5 \%$ & $1,5 \%$ & $1,5 \%$ & $1,5 \%$ & Pengemulsi \\
\hline EDTA & $10 \%$ & $10 \%$ & $10 \%$ & $10 \%$ & Humektan \\
\hline Aquadest & $0,5 \%$ & $0,5 \%$ & $0,5 \%$ & $0,5 \%$ & Pengawet \\
\hline
\end{tabular}

Keterangan:

$\mathrm{KN}$ : kontrol negatif

F : Formula 
Semua bahan yang akan digunakan ditimbang terlebih dahulu sesuai dengan takaran yang dianjurkan. Dimasukkan asam stearat sebanyak $3 \mathrm{~g}$ ke dalam gelas beker, kemudian ditambahkan $\mathrm{NaCl}$ sebanyak $1 \mathrm{~g}$ dan $\mathrm{NaOH}$ sebanyak 1,5 g, lalu dilarutkan dengan aquades sebanyak $20 \mathrm{ml}$ di atas penangas sambil diaduk hingga homogen. Ditambahkan EDTA

\section{Uji Efektivitas Antibakteri Sediaan} Sabun Cair Cuci Tangan Lendir Lidah

\section{Buaya}

Uji efektivitas antibakteri sabun cair cuci tangan lendir lidah buaya (Aloe barbadensis Miller) dengan cara membuat suspensi bakteri kemudian dimasukkan ke dalam cawan petri lalu ditambahkan medium. Dibiarkan memadat kemudian paper disk dicelupkan ke dalam masingmasing sampel uji, lalu diletakkan pada

\section{HASIL}

Hasil uji organoleptis sediaan sabun cair cuci tangan lendir lidah buaya minggu ke-0 sampai minggu ke-8 menunjukkan tidak terjadi perubahan sebanyak $0,5 \mathrm{~g}$ dan gliserin sebanyak $10 \mathrm{~g}$ ke dalam gelas beker dan diaduk hingga homogen. Dimasukkan lendir lidah buaya, diaduk hingga homogen. Sabun cair ditambahkan dengan aquades hingga volumenya $100 \mathrm{~mL}$, dimasukkan ke dalam wadah bersih yang telah disiapkan. Pembuatan sabun cair cuci tangan lendir lidah buaya disesuaikan.

permukaan media menggunakan pinset steril, diinkubasi pada suhu $37^{\circ} \mathrm{C}$ selama 24 jam dan diukur diameter zona hambat yang terbentuk.

\section{Evaluasi Fisik Sediaan Sabun Cair}

Evaluasi mutu sediaan meliputi uji organoleptis dan uji $\mathrm{pH}$ sediaan menggunakan alat $\mathrm{pH}$ meter secara duplo yang dilakukan pada minggu ke-0 sampai minggu ke-8 pada suhu kamar.

bentuk, warna dan bau, yakni cairan agak kental, tidak berbau, berwarna putih bening atau kekuningan, dapat dilihat pada gambar di bawah ini: 




\section{Gambar 1. Hasil Pengamatan Uji Organoleptis Sediaan Sabun Cair Cuci Tangan Lendir Lidah Buaya}

Hasil uji pH sediaan sabun cair lendir lidah buaya selama 8 minggu penyimpanan pada suhu kamar terhadap kontrol negatif maupun sampel formula I, formula II dan formula III berturut-turut menunjukkan nilai rata-rata $\mathrm{pH}$ sebagai berikut: 6,$37 ; 6,41 ; 6,34$ dan 6,35. Maka diperoleh nilai $\mathrm{pH}$ sediaan yakni 6,37 ; dapat dilihat pada tabel berikut ini:

Tabel 2. Hasil Pengukuran Nilai Rata-rata Uji pH Sediaan Sabun Cair Cuci Tangan Lendir Lidah Buaya

\begin{tabular}{ccccc}
\hline Minggu ke- & $\begin{array}{c}\text { Kontrol } \\
\text { Negatif }\end{array}$ & $\begin{array}{c}\text { Formula I } \\
(\text { F I) }\end{array}$ & $\begin{array}{c}\text { Formula II } \\
\text { (F II) }\end{array}$ & $\begin{array}{c}\text { Formula } \\
\text { III } \\
(\text { F III) }\end{array}$ \\
\hline 0 & 6,35 & 6,1 & 6,2 & 6,05 \\
\hline 1 & 6,45 & 6,6 & 6,4 & 6,5 \\
\hline 2 & 6,5 & 6,4 & 6,6 & 6,45 \\
\hline 3 & 6,3 & 6,7 & 6,2 & 6,75 \\
\hline 4 & 6,45 & 6,6 & 6,4 & 6,6 \\
\hline 5 & 6,5 & 6,3 & 6,4 & 6,4 \\
\hline 6 & 6,35 & 6,6 & 6,3 & 6,3 \\
\hline 7 & 6,0 & 6,2 & 6,15 & 6,0 \\
\hline 8 & 6,45 & 6,15 & 6,4 & 6,1 \\
\hline Rata-rata & $\mathbf{6 , 3 7}$ & $\mathbf{6 , 4 1}$ & $\mathbf{6 , 3 4}$ & $\mathbf{6 , 3 5}$ \\
\hline
\end{tabular}

Hasil uji efektivitas antibakteri sediaan sabun cair cuci tangan lendir lidah buaya dilakukan pada 3 formula dan 2 kontrol dengan duplokasi terhadap bakteri Eschericia coli menggunakan metode cakram dan Staphylococcus aureus menggunakan metode gores dengan pengamatan yang dilakukan tiap 3 jam sekali selama 24 jam menunjukkan sampel efektif menghambat pertumbuhan bakteri, dapat dilihat pada tabel berikut ini: 
Tabel 3. Hasil Pengukuran Zona Hambat Bakteri Eschericia coli dengan Metode Cakram Rata-rata

Diameter Zona Hambat (mm)

\begin{tabular}{|c|c|c|c|c|}
\hline \multirow{2}{*}{ Sampel Sediaan } & \multicolumn{4}{|c|}{ loat (mm) } \\
\hline & 3 Jam & $6 \mathrm{jam}$ & 9 Jam & 24 Jam \\
\hline Kontrol Positif & 4,4 & 6,17 & 7,64 & 14,85 \\
\hline Kontrol Negatif & 3,15 & 4,28 & 6,34 & 14,54 \\
\hline Formula I (3\%) & 4,67 & 6,72 & 9,17 & 19,87 \\
\hline Formula II $(6 \%)$ & 5,49 & 7,52 & 9,84 & 21,09 \\
\hline Formula III (9\%) & 6,32 & 8,42 & 10,27 & 21,45 \\
\hline
\end{tabular}

Tabel 4. Hasil Pengukuran Zona Hambat Bakteri Staphylococcus aureus dengan Metode Cakram

\begin{tabular}{ccccc}
\hline & \multicolumn{4}{c}{ Riameter Zona Hambat (mm) } \\
\cline { 2 - 5 } Sampel Sediaan & 3 Jam & $\mathbf{6 ~ j a m}$ & $\mathbf{9}$ Jam & 12 Jam \\
\hline Kontrol Positif & 5,53 & 6,62 & 8,54 & 13,24 \\
\hline Kontrol Negatif & 2,75 & 4,37 & 5,48 & 10,07 \\
\hline Formula I (3\%) & 5,54 & 6,98 & 8,7 & 13,25 \\
\hline Formula II (6\%) & 5,78 & 7,55 & 8,82 & 13,5 \\
\hline Formula III (9\%) & 5,9 & 7,78 & 9,01 & 13,72 \\
\hline
\end{tabular}

\section{DISKUSI}

Pada penelitian ini dilakukan evaluasi fisik sediaan meliputi uji organoleptis dan uji $\mathrm{pH}$. Evaluasi fisik sediaan bertujuan untuk mengetahui fisik sediaan yang terjadi pada suatu produk atau sampel (Wulandari, 2008).

Uji organoleptis bertujuan untuk mengetahui perubahan warna, bentuk dan bau selama penyimpanan (Sriwidodo, 2013). Berdasarkan gambar 1 hasil pengamatan uji organoleptis sediaan sabun cair cuci tangan yang mengandung lendir lidah buaya dengan konsentrasi $3 \%$, $6 \%$, 9\% maupun kontrol negatif menunjukkan tidak terjadinya perubahan pada bentuk, warna dan bau selama 8 minggu penyimpanan pada suhu kamar, yakni sediaan tetap berbentuk cairan agak kental, tidak berbau, berwarna putih bening atau kekuningan. Hal ini sesuai dengan penelitian sebelumnya mengenai uji organoleptis sediaan sabun cair cuci tangan dari lendir lidah buaya yang menyatakan bahwa sediaan stabil selama 8 minggu penyimpanan baik dari segi penampilan, warna dan bau (Sriwidodo, 2013).

Uji pH bertujuan untuk mengetahui $\mathrm{pH}$ sediaan selama penyimpanan dalam jangka waktu yang lama dan menyesuaikan syarat yang telah ditetapkan oleh SNI yaitu 4,5-8 untuk 
sabun cair cuci tangan (Sriwidodo, 2013). Berdasarkan tabel 2 hasil pengukuran nilai rata-rata uji $\mathrm{pH}$ sediaan sabun cait cuci tangan lendir lidah buaya selama 8 minggu penyimpanan pada suhu kamar terhadap kontrol negatif maupun formula I, formula II dan formula III menunjukkan tidak terjadinya perubahan $\mathrm{pH}$ yang signifikan dan diperoleh rentan nilai sediaan yang berkisar antara 6,37 . Hal ini sesuai dengan penelitian sebelumnya mengenai uji $\mathrm{pH}$ sediaan sabun cair cuci tangan dari lendir lidah buaya yang menyatakan bahwa $\mathrm{pH}$ sediaan stabil selama 8 minggu penyimpanan pada suhu kamar (Sriwidodo, 2013). Menurut hasil pengamatan dan penelitian sebelumnya, maka formulasi sediaan sabun cair cuci tangan dari lendir lidah buaya memiliki $\mathrm{pH}$ yang stabil dalam penyimpanan dengan nilai $\mathrm{pH} 6,37$; hal ini sesuai syarat $\mathrm{pH}$ yang telah ditetapkan oleh SNI untuk sediaan sabun cair yaitu 4,5-8.

Uji efektivitas sediaan sabun cair cuci tangan adalah untuk mengetahui apakah lendir lidah buaya dapat berfungsi sebagai antibakteri dengan menghambat pertumbuhan bakteri Eschericia coli dan Staphlococcus aureus yang merupakan bakteri patogen pada manusia (Dyah Ayu, 2013). Pengujian efektivitas antibakteri sediaan sabun cair cuci tangan dilakukan dengan mengukur diameter zona hambat sampel sediaan sabun cair cuci tangan dari lendir lidah buaya maupun kontrol positif (Dettol 9\%) dan kontrol negatif secara duplo terhadap bakteri Eschericia coli menggunakan metode cakram dan Staphylococcus aureus menggunakan metode gores yang diamati tiap 3 jam sekali selama 24 jam.

Berdasarkan tabel 3 hasil pengukuran zona hambat bakteri Eschericia coli dilakukan pengamatan tiap 3 jam sekali selama 24 jam terhadap kontrol positif, kontrol negatif maupun sampel berturut-turut dengan rata-rata diameter zona hambat masing-masing sebagai berikut: Kontrol Positif yaitu 4,4 $\mathrm{mm} ; 6,17 \mathrm{~mm} ; 7,64 \mathrm{~mm}$ dan $14,85 \mathrm{~mm}$, Kontrol Negatif yaitu 3,15 mm; 4,28 mm; $6,34 \mathrm{~mm}$ dan $14,54 \mathrm{~mm}$, Formula I yaitu 4,67 mm; 6,72 mm; 9,17 $\mathrm{mm}$ dan 19,87 $\mathrm{mm}$, Formula II yaitu $5,49 \mathrm{~mm} ; 7,52 \mathrm{~mm}$; 9,84 mm dan 21,09 mm serta Formula III yaitu $6,2 \mathrm{~mm} ; 8,42 \mathrm{~mm} ; 10,27 \mathrm{~mm}$ dan 21,45 mm. Hasil pengukuran tersebut dapat terlihat adanya perbedaan yang cukup signifikan pada formula I, II dan III dibandingkan dengan kontrol positif. Namun formula III memiliki daya hambat bakteri yang lebih baik dibanding formula I dan formula II.

Berdasarkan tabel 4 hasil pengukuran zona hambat bakteri Staphylococcus aureus dilakukan pengamatan tiap 3 jam sekali selama 24 jam terhadap kontrol positif, kontrol 
negatif maupun sampel berturut-turut dengan rata-rata diameter zona hambat masing-masing sebagai berikut: Kontrol Positif yaitu 5,53 mm; 6,62 mm; 8,54 mm dan 13,24 mm, Kontrol Negatif yaitu 2,75 $\mathrm{mm} ; 4,37 \mathrm{~mm} ; 5,48 \mathrm{~mm}$ dan $10,07 \mathrm{~mm}$, Formula I yaitu $5,54 \mathrm{~mm} ; 6,98 \mathrm{~mm} ; 8,7$ $\mathrm{mm}$ dan $13,25 \mathrm{~mm}$, Formula II yaitu 5,78 $\mathrm{mm} ; 7,55 \mathrm{~mm} ; 8,82 \mathrm{~mm}$ dan $13,55 \mathrm{~mm}$ sedangkan Formula III yaitu 5,9 mm; 7,78 $\mathrm{mm} ; 9,1 \mathrm{~mm}$ dan 13,72 mm. Dari hasil pengukuran tersebut dapat terlihat tidak adanya perbedaan yang signifikan baik kontrol negatif, formula I, formula II dan formula III terhadap kontrol positif. Namun formula III memiliki daya hambat bakteri yang lebih baik dibanding formulaI dan II.

Berdasarkan hasil pengukuran diameter zona hambat terhadap kedua bakteri tersebut maka diperoleh hasil bahwa sediaan sabun cair cuci tangan dari lendir lidah buaya efektif menghambat pertumbuhan bakteri. Hal ini disebabkan oleh adanya senyawa aktif antibakteri yang terkandung dalam lendir lidah buaya yaitu saponin (Widodo, 2013). Saponin terdapat pada cairan bening seperti jeli diperoleh dengan membelah batang lidah buaya. Jeli ini mengandung zat antibakteri dan anti jamur yang dapat menstimulasi fibroblast yaitu sel-sel kulit yang berfungsi menyembuhkan luka (Sulaeman, 2008). Adapun senyawa lain yang berpotensi sebagai antibakteri yaitu emodien antrakuinon yang sebelumnya telah terbukti memiliki aktivitas antimikroba. Antrakuinon bekerja dengan cara menghambat sintesis protein sehingga bakteri tersebut tidak dapat tumbuh dalam media yang terdapat lendir lidah buaya (Teresya Puteri, 2013).

Kriteria kekuatan daya antibakteri dikategorikan berdasarkan diameter zona hambat yang terbentuk yaitu diameter zona hambat $5 \mathrm{~mm}$ atau kurang dikategorikan lemah, zona hambat 5-10 $\mathrm{mm}$ dikategorikan sedang, zona hambat 10-20 mm dikategorikan kuat dan zona hambat $20 \mathrm{~mm}$ atau lebih dikategorikan sangat kuat (Davis dan Stout, 1971).

Hasil uji efektivitas sediaan sabun cair cuci tangan dari lendir lidah buaya dilihat dari pengukuran diameter zona hambatnya terhadap bakteri Eschericia coli dan Staphylococcus aureus menunjukkan bahwa tidak terdapat perbedaan yang signfikan antara sampel sediaan yaitu kontrol negatif, formula I, II dan III dengan kontrol positif. Namun pada formula III memiliki daya hambat yang lebih baik dibandingkan formula I dan II. Berdasarkan kategori di atas, maka daya antibakteri sediaan sabun cair cuci tangan dari lendir lidah buaya pada bakteri Eschericia coli dengan konsentrasi 9\% (21,45 mm) dikategorikan sangat kuat, konsentrasi 6\% (21,09 mm) 
dikategorikan sangat kuat, konsentrasi 3\%

$(19,87 \mathrm{~mm})$ dikategorikan kuat, sedangkan terhadap bakteri Staphylococcus aureus dengan konsentrasi 9\% (13,72 $\mathrm{mm})$, konsentrasi $6 \%(13,5 \mathrm{~mm})$ dan konsentrasi 3\% (13,25

\section{SIMPULAN}

Berdasarkan hasil penelitian maka dapat disimpulkan bahwa lendir lidah buaya dapat diformulasikan menjadi sabun cair cuci tangan dengan konsentrasi $3 \%$, 6\% dan 9\%. Hasil evaluasi fisik sediaan meliputi uji organoleptis dan uji pH menunjukkan bahwa sediaan sabun cair cuci tangan lendir lidah buaya tidak ada perubahan yang signifikan atau dapat dikatakan baik dalam penyimpanan selama 8 minggu penyimpanan. Hasil uji efektivitas antibakteri sabun cair cuci

\section{DAFTAR PUSTAKA}

Alfarisi dan Timmreck 2008. Pentingnya Menjaga Kebersihan. Jakarta: Rineka Cipta.

Anonim, 2008, "Water Hardness: EDTA Titrametic Method, New York USA". Arifin, 2011. Pembuatan dan Karakteristik Sabun Cair dengan bahan tambahan Ekstrak Jeruk Nipis (Citrus Aurantifolia S.), Tesis, Program Parscasarjana, Universitas Andalas.

BPOM RI, 2008. "Buku Acuan Sediaan Herbal" Volume Keempat Edisi Pertama: Jakarta. mm) dikategorikan kuat. Hal ini disebabkan perbedaan konsentrasi lendir lidah buaya pada tiap formulasi, dimana semakin tinggi konsentrasi lendir lidah buaya yang digunakan, maka semakin besar pula daya hambat bakterinya.

tangan lendir lidah buaya dapat menghambat bakteri Eschericia coli dan Staphylococcus aureus dengan konsentrasi 9\% sebagai konsentrasi paling efektif, yakni pada bakteri Eschericia coli konsentrasi $6 \%$ dan 9\% masuk dalam kategori zona hambat yang sangat kuat, konsentrasi 3\% masuk dalam kategori zona hambat yang kuat. Pada bakteri Staphylococcus aureus konsentrasi 3\%, 6\% dan 9\% masuk dalam kategori zona hambat yang kuat.

Candra, 2009. Kandungan Lidah Buaya, Fakultas Kedokteran Gigi Universitas Indonesia Siswanto, 2010. Mencuci Tangan dengan Sabun, Jakarta: Departemen Kesehatan RI.

Dirjen POM, 1979, "Farmakope Indonesia", Edisi III, Departemen Kesehatan RI, Jakarta.

Dirjen POM, 1995, "Farmakope Indonesia", Edisi IV, Departemen Kesehatan RI, Jakarta.

Dyah Ayu, 2013. Uji Efektivitas Sabun Cair dari Ekstrak Daun Pepaya 
(Carica Papaya L.) Terhadap Staphylococcus aureus . Skripsi Fakultas Farmasi, Universitas Indonesia Timur Makasar, Makasar.

Furnawanthi, 2007. Khasiat dan Manfaat Lidah Buaya. Kanisius. Jakarta.

Gusvi Putri et al, 2013. Pembuatan Sabun dengan Lidah Buaya (AloeVera) Sebagai Antiseptik Alami (Jurnal Volume 12 No.1). Widya. Teknik. Surabaya.

Haley S., 2009. "Handbook Of Herbeser, 2011. Pengertian Sabun dan Fungsinya. Penebar Swadaya, Jakarta.

Herbesser, 2011. Pengertian Sabun dan Fungsinya. Penebar Swadaya, Jakarta.

Lukman, 2012. Pembuatan Sabn Mandi Padat dari VCO yang Mengandung Karotenoid Wortel, Jur. MIPA UNSRAT 20-23.

Pratiwi, 2008. Mikrobiologi Farmasi. Yogyakarta: Penerbit Erlangga. Halaman 176.

Pratiwi, Sylvia T, 2008, "Mikrobiologi Farmasi”. Erlangga, Bandung.

Proverawati, dan Rahmawati, 2012. Perilaku Hidup Bersih dan Sehat. Jakarta: Departemen Kesehatan RI.

Qisti, 2009. Sifat Kimia Sabun Transparan dengan Penambahan Madu pada Konsentrasi yang berbeda, Skripsi, Fakultas Peternakan, Institusi Pertanian Bogor, Bogor.

Satrias Apgar, 2010. "Formulasi Sabun Mandi Cair yang Mengandung Gel Daun Lidah Buaya (Aloe vera L.) dengan Basis Virginia Coconut Oil (VCO)”, Tugas Akhir Sarjana
Farmasi, Jurusan Farmasi, FMIPAUniversitas Islam Bandung.

Siswanto, 2010. Mencuci Tangan dengan Sabun, Jakarta: Departemen Kesehatan RI.

SNI 06-2588., 1992. Sabun Cair Cuci Tangan. Jakarta : Badan Standarisasi Nasional.

Sriwidodo, 2013. "Formulasi Sabun Cair dengan Lendir Lidah Buaya". Jurusan Farmasi FMIPA UNPAD, Jatinangor, Sumedang.

Sulaeman, 2008. Kandungan Saponin pada lidah buaya jenis Barbadensis Miller. Program Diploma Fakultas Teknik, Diponegoro, Semarang. Semarang.

Syahrurahman dkk., 2010. "Uji Aktivitas Antibakteri Minyak Daun Ruku-Ruku (Ocinum Sanctum L.) Terhadap Bakteri Staphylococcus aureus".

Teresya Puteri, 2013. "Uji Daya Hambat Ekstrak Lidah Buaya (Aloe vera .L.) Terhadap Bakteri Eschericia coli dan Staphylococcus aureus ". Fakultas Farmasi Universitas Padjajaran.

Todar, 2008. Uji Aktivitas Antibakteri Minyak Atsiri Kulit Buah Jeruuk Nipis (Citrus Aurantifolia S.) Terhadap Sthapylococus aureus dan Eschericia coli , Skripsi, Fakultas Farmasi, Universitas Muhammadiyah Surakarta, Sukrakarta.

Utami, 2012. Kajian Penggunaan Lidah Buaya (Aloe Vera) pada Pembuatan Sabun, J. Tek. Ind. Pert, 15 (2), 4045.

Wasitaatmaja, 1997. Penuntun Ilmu Kosmetik Medik, Jakarta. 